\title{
Biogas yield from Sicilian kitchen waste and cheese whey
}

\author{
Antonio Comparetti, ${ }^{1}$ Pierluigi Febo, ${ }^{1}$ Carlo Greco, ${ }^{1}$ Santo Orlando, ${ }^{1}$ Kestutis Navickas, ${ }^{2}$ \\ Arvydas Nekrosius, ${ }^{2}$ Kestutis Venslauskas ${ }^{2}$ \\ ${ }^{1}$ Dipartimento di Scienze Agrarie e Forestali, Università degli Studi di Palermo, Italy; ${ }^{2}$ Institute of \\ Energy and Biotechnology Engineering, Aleksandras Stulginskis University, Akademija, Kauno r., \\ Lithuania
}

\begin{abstract}
The aim of this study is to determine the chemical composition of kitchen waste and cheese whey, as well as the biogas yield obtained from the Anaerobic Digestion (AD) tests of these two raw materials.

Since the separated waste collection is performed in the town of Marineo (Palermo), a sample of kitchen waste, different from food industry one and included in the Organic Fraction of Municipal Solid Waste (OFMSW), was collected from the mass stored at the households of this town. Moreover, a sample of cheese whey was collected in a Sicilian mini dairy plant, where sheep milk is processed. This investigation was carried out inside laboratory digesters of Aleksandras Stulginskis University (Lithuania). Total Solids (TS) resulted 15.6\% in kitchen waste and $6 \%$ in cheese whey, while both the raw materials showed a high content of organic matter, $91.1 \%$ and $79.1 \%$, respectively. The biogas yield resulted $104.6 \mathrm{I} \mathrm{kg}^{-1}$ from kitchen waste and $30.6 \mathrm{l}$ $\mathrm{kg}^{-1}$ from cheese whey. The biogas yield from TS resulted $672.6 \mathrm{I} \mathrm{kg}^{-1}$ using kitchen waste and $384.7 \mathrm{I} \mathrm{kg}^{-1}$ using cheese whey. The biogas yield from Volatile Solids (VS) resulted $738.9 \mathrm{I} \mathrm{kg}^{-1}$ using kitchen waste and $410.3 \mathrm{I} \mathrm{kg}^{-1}$ using cheese whey.
\end{abstract}

\section{Introduction}

The Organic Fraction of Municipal Solid Waste (OFMSW) and/or food industry by-products (e.g. cheese whey) and/or animal manure

\footnotetext{
Correspondence: Carlo Greco, Dipartimento di Scienze Agrarie e Forestali, Università degli Studi di Palermo, Viale delle Scienze, Building 4, 90128 Palermo, Italy.

Tel. +39.091.23897057 - Fax: +39.091.484035.

E-mail: carlo.greco@unipa.it

Keywords: anaerobic digestion, biogas yield, cheese whey, kitchen waste.

Contributions: the authors contributed equally.

Conflict of interests: the authors declare no potential conflict of interests.

CC Copyright A Comparetti et al., 2013

Licensee PAGEPress, Italy

Journal of Agricultural Engineering 2013; XLIV(s2):e106

doi:10.4081/jae.2013.s2.e106

This article is distributed under the terms of the Creative Commons Attribution Noncommercial License (by-nc 3.0) which permits any noncommercial use, distribution, and reproduction in any medium, provided the original author(s) and source are credited.
}

can be processed through Anaerobic Digestion (AD), in order to produce biogas and "digestate". The biogas, mostly containing methane, can be transferred to the natural gas distribution pipeline or Combined Heat and Power (CHP) plants or used as vehicle fuel, while the digestate can be used as bio-fertiliser.

The chemical composition of OFMSW and, therefore, the yield of $\mathrm{AD}$ process, is influenced by several factors, including climate, collection frequency and method, season, cultural practices, as well as changes in its solid components (Tchobanoglous et al., 1997; Mace et al., 2000; Pavan et al., 2000; Saint-Joly et al., 2000; Bolzonella et al., 2003a, $2003 \mathrm{~b}, 2005)$. Several papers focused on the AD of organic wastes according to their origin, e.g. OFMSW (Bolzonella et al., 2005), household (Krzystek et al., 2001) and kitchen waste (Rao and Singh, 2004). Many examples exist on the use of AD to treat the mechanically separated biodegradable fraction of municipal waste (Mata-Alvarez, 2003). There are also examples of the processing of mixed source segregated biodegradable wastes, e.g. kitchen and garden wastes (Archer et al., 2005), but there are only a few reports on $\mathrm{AD}$ plants entirely processing household food waste separated at source (Banks et al., 2011). The interest in this process is growing in Europe, due to the rising energy costs of wet waste processing, the requirement to meet the targets of the EU Landfill Directive (99/31/EC) (EU, 1999) and the need to comply with regulations for the disposal of animal by-products (EU, 2002). According to the regulations of many European countries, whether the waste is not separated at source but the organic fraction is recovered through a Mechanical-Biological Treatment (MBT) plant, the digestate produced is not allowed to be applied on land (Stretton-Maycock and Merrington, 2009). As a consequence, governments and industry are strongly interested in the AD methods of household food waste separated at source (Banks et al., 2011).

Furthermore, kitchen waste was also surveyed as co-substrate for AD (Angelidaki and Ahring, 1997; Brinkman, 1999; Comparetti et al., 2013). Anaerobic co-digestion of mixtures including food industry by-products and animal manure was previously investigated and, among these mixtures, particular interest was paid to the co-digestion of animal manure and cheese whey (Ghaly, 1996; Gelegenis et al., 2007). Several authors focused on the AD of cheese whey for biogas production (Lo and Liao, 1986; Yan et al., 1989; Ghaly and Pyke, 1991). Some studies showed that the co-digestion of cheese whey and other substrata (i.e. maize silage, beet pulp, carrot residues and glycerine fraction) can be advantageous inside lab-scale bio-reactors (Kacprzak et al., 2010).

In this perspective the aim of this study is to determine the chemical composition of kitchen waste and cheese whey, as well as the biogas yield obtained from the $\mathrm{AD}$ tests of these two raw materials.

\section{Materials and methods}

Since the separated waste collection is performed in the town of 
Marineo (Palermo), a sample of kitchen waste, different from food industry one and included in the Organic Fraction of Municipal Solid Waste (OFMSW), was collected from the mass stored at the households of this town in a day of March 2012.

Moreover, a sample of cheese whey was collected in a Sicilian mini dairy plant, located in Ventimiglia di Sicilia (Palermo) and processing sheep milk, in the same day.

The two samples were transported to the Institute of Energy and Biotechnology Engineering of Aleksandras Stulginskis University (Lithuania).

In the laboratory of this institute, the Total Solids concentration (TS) was determined in each of the two samples, by drying it in an oven at $105 \pm 2{ }^{\circ} \mathrm{C}$ temperature for 24 hours, as well as Volatile Solids concentration (VS), by burning it at $500{ }^{\circ} \mathrm{C}$ temperature. Total organic Carbon concentration $\left(\mathrm{C}_{\mathrm{T}}\right)$ was determined in each sample, by using an analyser TOC II, as well as Total Nitrogen concentration $\left(\mathrm{N}_{\mathrm{T}}\right)$, by using a Kjeldahl apparatus.

The $\mathrm{AD}$ tests were carried out in two laboratory scale anaerobic digesters under controlled temperature $\left(38 \pm 0.5^{\circ} \mathrm{C}\right)$. The sample of kitchen waste (having a mass of $336 \mathrm{~g}$ ) was added to a laboratory digester, consisting of stainless steel vessels (having a volume of 20 l) equipped with a substrate mixer (having a mixing intensity of 60 $\mathrm{min}^{-1}$ ). Instead, the sample of cheese whey (having a mass of $26 \mathrm{~g}$ ) was added to a digester having a volume of $0.5 \mathrm{l}$. The biogas produced was collected at the top of each digester and conveyed, through a drum type flow meter, to a gasholder (Tedlar® bag, having a volume of $25 \mathrm{l}$ ). Later the biogas collected was analysed by using a Schmack SSM 6000 biogas analyser.

The $\mathrm{AD}$ tests of kitchen waste were performed in three replications and those of cheese whey in nine replications.

The $\mathrm{AD}$ results of kitchen waste and cheese whey were evaluated by means of the following indicators: biogas production intensity $b$, biogas yield from biomass $B_{M}$, biogas yield from biomass Total Solids $B_{T S}$, biogas yield from biomass Volatile Solids $B_{V S}$, energy obtained from biomass $e_{M}$, from biomass Total Solids $e_{T S}$ and from biomass Volatile Solids $e_{V S}$. Biogas production intensity $b$ indicates the volume of biogas produced during the time of biomass biological degradation. Biogas yield from biomass $B_{M}$, from biomass Total Solids $B_{T S}$ and from biomass Volatile Solids $B_{\mathrm{VS}}$ was calculated by means of the following equations (Navickas et al., 2003) :

$$
B_{M}=\frac{b_{d t}}{m} ; \quad B_{t s}=\frac{b_{d t}}{m_{r s}} ; \quad B_{v s}=\frac{b_{d t}}{m_{v s}}
$$

where :

$b_{d t}$ is the volume (l) of the biogas produced (in laboratory) during the time interval $d t$ (duration of biomass biological degradation);

$m$ is the mass $(\mathrm{kg})$ of the biomass sample analysed;

$m_{T S}$ is the mass $(\mathrm{kg})$ of Total Solids in the biomass sample;

$m_{V S}$ is the mass $(\mathrm{kg})$ of Volatile Solids in the biomass sample.

The energy obtained during $\mathrm{AD}$ from biomass $e_{M}, e_{T S}, e_{V S}$ was determined by means of the following equations :

$$
e_{M}=B_{M} \cdot e_{b} ; \quad e_{T S}=B_{T S} \cdot e_{b} ; \quad e_{V S}=B_{V S} \cdot e_{b}
$$

where :

$e_{b}$ is the energetic value of biogas $\left(\mathrm{MJ} \cdot \mathrm{m}^{-3}\right)$, depending on methane concentration in biogas (\%).

The energetic value of biogas was determined by means of the following equation :

$e_{b}=0.0353 \cdot \frac{C_{M}}{100}$ where :

$C_{M}$ is the methane concentration in biogas (\%).

\section{Results and discussion}

The chemical composition of kitchen waste and cheese whey samples are shown in Table 1. Total Solids (TS) resulted $15.6 \%$ in kitchen waste and $6 \%$ in cheese whey, while both the raw materials showed a high content of organic matter, $91.1 \%$ and $79.1 \%$, respectively.

Optimum $\mathrm{C} / \mathrm{N}$ ratios are generally in the $20-30$ range in anaerobic digesters (Themelis and Verma, 2004; Ward et al., 2008). The $\mathrm{C} / \mathrm{N}$ ratio of kitchen waste resulted 17.4, while that of cheese whey resulted 23.1. Therefore, both values can be assumed to be optimal for AD process. However, Ward et al. (2008) reported in a review article that, after an acclimation period, anaerobic bacteria also accept lower $\mathrm{C} / \mathrm{N}$ ratios (approximately 9).

The results of $\mathrm{AD}$ tests, whose duration was five days using kitchen waste and four days using cheese whey, are shown in Table 2.

The biogas yield resulted $104.6 \mathrm{I} \mathrm{kg}^{-1}$ from kitchen waste and $30.6 \mathrm{l} \mathrm{kg}$ ${ }^{1}$ from cheese whey. The biogas yield from TS resulted $672.6 \mathrm{l} \mathrm{kg}^{-1}$ using kitchen waste (Figure 1) and $384.7 \mathrm{~kg}^{-1}$ using cheese whey (Figure 2).

Table 1. Chemical composition of kitchen waste and cheese whey samples.

\begin{tabular}{lccc} 
Parameter & Measurement unit & Kitchen waste & Cheese whey \\
Total Solids (TS) & $\%$ & 15.6 & 6.0 \\
Organic matter (in TS) & $\%$ & 91.1 & 79.1 \\
\hline Organic Carbon & $\%$ & 5.69 & 2.29 \\
Total Nitrogen & $\%$ & 0.328 & 0.099 \\
\hline C/N ratio & - & 17.4 & 23.1
\end{tabular}

Table 2. Results of AD tests.

\begin{tabular}{lccc}
\hline Indicator & Rate & Kitchen waste & Cheese whey \\
\hline Biogas yield from biomass, $B_{M}$ & $\quad l \cdot \mathrm{kg}^{-1}$ & 104.6 & 30.6 \\
\hline Biogas yield from Total Solids, $B_{T S} l \mathrm{~kg}^{-1}$ & 672.6 & 384.7 \\
\hline Biogas yield from Volatile Solids, $B_{V S} l \cdot \mathrm{kg}^{-1}$ & 738.9 & 410.3 \\
\hline
\end{tabular}

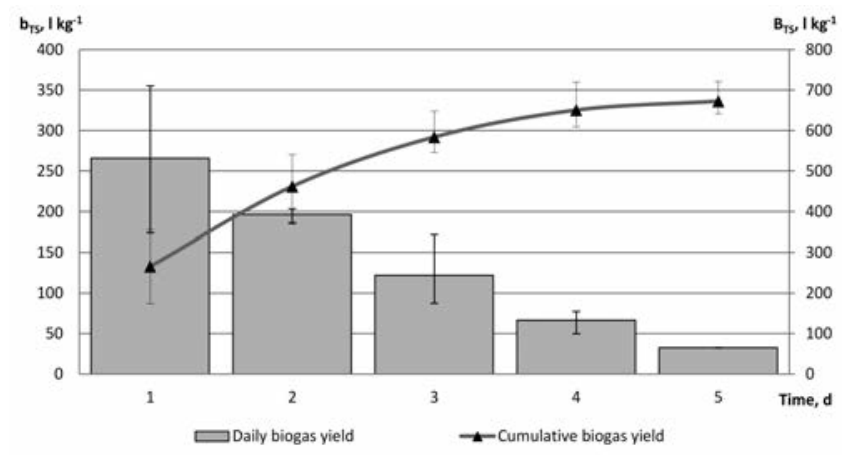

Figure 1. Biogas yield from Total Solids (TS) obtained using kitchen waste during $\mathrm{AD}$ tests: the histograms are the daily yield $\boldsymbol{b}_{T S}$, while the curve is the total cumulative yield $B_{T S}$. 
The biogas yield from Volatile Solids (VS) resulted $738.9 \mathrm{l} \mathrm{kg}^{-1}$ using kitchen waste (Figure 3) and $410.3 \mathrm{l} \mathrm{kg}^{-1}$ using cheese whey (Figure 4).

Furthermore, other indicators were determined for the kitchen waste sample: methane concentration in biogas of $61.9 \%$, energy obtained from biomass $\left(e_{M}\right)$ of $2.28 \mathrm{MJ} \cdot \mathrm{kg}^{-1}$, energy obtained from dry matter $\left(e_{T S}\right)$ of $14.67 \mathrm{MJ} \cdot \mathrm{kg}^{-1}$ and energy obtained from organic matter $\left(e_{V S}\right)$ of $16.13 \mathrm{MJ} \cdot \mathrm{kg}^{-1}$.

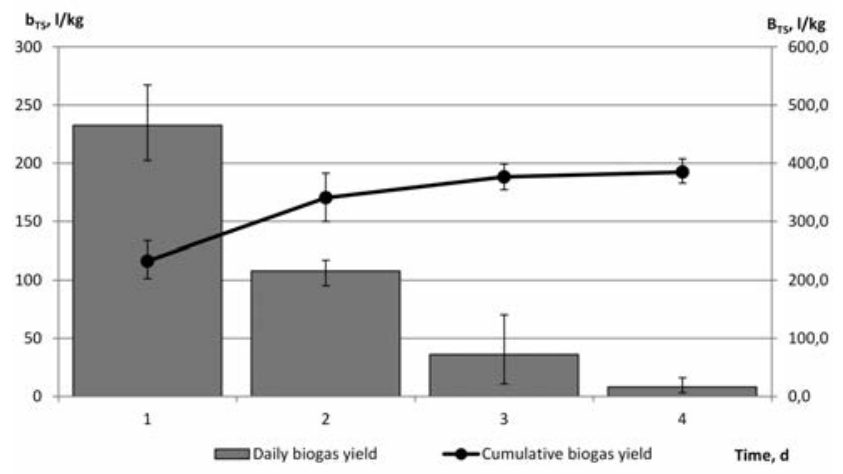

Figure 2. Biogas yield from Total Solids (TS) obtained using cheese whey during $\mathrm{AD}$ tests: the histograms are the daily yield $b_{T S}$, while the curve is the total cumulative yield $B_{T S}$.

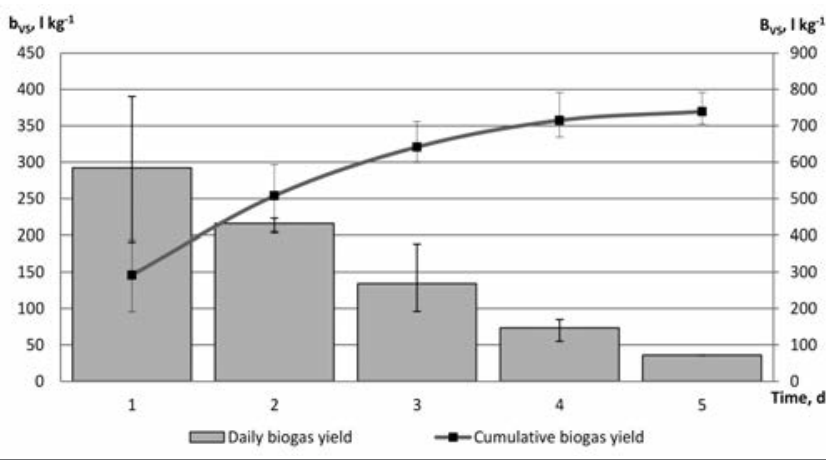

Figure 3. Biogas yield from Volatile Solids (VS) obtained using kitchen waste during $\mathrm{AD}$ tests: the histograms are the daily yield $b_{V S}$, while the curve is the total cumulative yield $B_{V S}$.

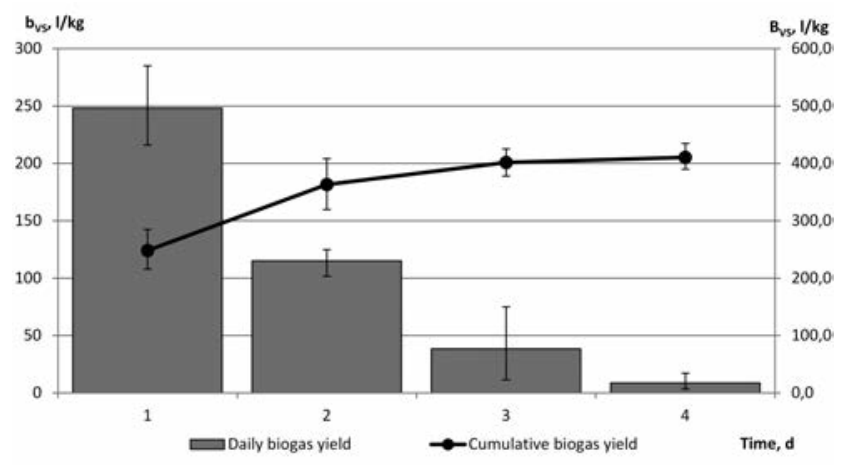

Figure 4. Biogas yield from Volatile Solids (VS) obtained using cheese whey during $\mathrm{AD}$ tests: the histograms are the daily yield $b_{V S}$, while the curve is the total cumulative yield $B_{V S}$.
Therefore, the biogas yield from VS using both the processed raw materials was comparable with the results of Banks et al. (2011) (642 $1 \cdot \mathrm{kg}^{-1}$ with a methane concentration of $62 \%$ ) and Bolzonella et al. (2006) $\left(700 \mathrm{l} \cdot \mathrm{kg}^{-1}\right.$ and $180 \mathrm{l} \cdot \mathrm{kg}^{-1}$ from sorted OFMSW with a methane concentration of 56\%). However, the biogas yield from organic matter could be temporally variable, due to changing life style and consumed food composition.

\section{Conclusions}

Both kitchen waste and cheese whey are reasonable raw materials for biogas production, in terms of Total Solids (TS) and organic matter content, while the $\mathrm{C} / \mathrm{N}$ ratio obtained (17-23) can be assumed to be optimal for $\mathrm{AD}$ process.

The time of biomass biological degradation was five days using kitchen waste and four days using cheese whey.

The biogas yield obtained using kitchen waste was $104.6 \mathrm{l} \mathrm{kg}^{-1}$ from biomass, $672.6 \mathrm{l} \mathrm{kg}^{-1}$ from TS and $738.9 \mathrm{l} \mathrm{kg}^{-1}$ from Volatile Solids (VS). The biogas yield obtained using cheese whey was $30.6 \mathrm{l} \mathrm{kg}^{-1}$ from biomass, $384.7 \mathrm{l} \mathrm{kg}^{-1}$ from TS and $410.3 \mathrm{l} \mathrm{kg}^{-1}$ from VS.

Waste management is a problem to be solved not only in Sicily but in the whole Italy, where the landfill sites have been or will be filled in with MSW very soon, as well as people don't accept the use of new sites in their municipal land. Moreover, the measures aimed at promoting segregated waste collection have been only scarcely implemented in Italy, where the environmentalist movements always fight against the building of incinerators, as well as the inefficient waste management has often caused public health problems in whole cities (e.g. Naples and Palermo).

In this perspective politicians should promote the valorisation of organic wastes (e.g. kitchen waste and cheese whey) through $\mathrm{AD}$ process. In fact, whether kitchen waste was anaerobically digested, it would highly reduce the OFMSW amount that is nowadays aerobically composted or, even worse, landfilled. Moreover, even if the biogas yield from cheese whey resulted about three times lower than that from kitchen waste, the $\mathrm{AD}$ of the liquid waste of dairies and mini dairy plants is an interesting option that would solve the problem of its disposal, better than others, i.e. purification, aerobic composting and feeding of pigs. These policy measures would contribute to reduce $\mathrm{CO}_{2}$ emission and, therefore, global warming.

\section{References}

Angelidaki I., Ahring B.K. 1997. Codigestion of olive oil mill wastewaters with manure, household waste or sewage sludge. Biodegradation 8(4):221-6.

Archer E., Baddeley A., Klein A., Schwager J., Whiting K. 2005. MBT: A Guide for Decision Makers - Processes, Policies and Markets. Juniper Consulting Ltd., Uley, Gloucestershire, UK.

Banks C.J., Chesshire M., Heaven S., Arnold R. 2011. Anaerobic digestion of source-segregated domestic food waste: Performance assessment by mass and energy balance. Bioresource Technol 102:612-20.

Bolzonella D., Battistoni P., Mata-Alvarez J., Cecchi F. 2003a. Anaerobic digestion of organic solid wastes: process behaviour in transient conditions. Water Sci Technol 48(4):1-8.

Bolzonella D., Innocenti L., Pavan P., Traverso P., Cecchi F. 2003b. Semidry thermophilic anaerobic digestion of the organic fraction of municipal solid waste: focusing on the start-up phase. Bioresource Technol 86(2):123-9. 
Bolzonella D., Pavan P., Fatone F., Cecchi F. 2005. Anaerobic fermentation of organic municipal solid wastes for the production of soluble organic compounds. Ind Eng Chem Res 44(10):3412-8.

Bolzonella D., Pavan P., Mace S., Cecchi F. 2006. Dry anaerobic digestion of differently sorted organic municipal solid waste: a full-scale experience. Water Sci Technol 53(8):23-32.

Brinkman J. 1999. Anaerobic digestion of mixed slurries from kitchens, slaughterhouses and meat processing industries. In: J. Mata Alvarez., A. Tilche and F. Cecchi (Editors), Proceedings of the $2^{\text {nd }}$ Int. Symp. on Anaerobic Digestion of Solid Waste, Barcelona, Spain, 15-18 June, pp. 190-195.

Comparetti A., Febo P., Greco C., Orlando S. 2013. Current state and future of biogas and digestate production, Bulg J Agric Sci 19(1):1-14.

European Union, 1999. Council Directive 99/31/EC of 26 April 1999 on the landfill of waste. In: Official Journal of the European Communities, 182, 16/07/1999, pp 1-19.

European Union, 2002. Regulation (EC) 1774/2002 of the European Parliament and of the Council, 03/10/2002, laying down health rules concerning animal by-products not intended for human consumption.

Gelegenis J., Georgakakis D., Angelidaki I., Mavris V. 2007. Optimization of biogas production by co-digesting whey with diluted poultry manure. Renew Energ 32:2147-60.

Ghaly A.E., Pyke J.B. 1991. Amelioration of methane yield in cheese whey fermentation by controlling the $\mathrm{pH}$ of the methanogenic stage. Appl Biochem Biotech 27:217-37.

Ghaly A.E. 1996. A comparative study of anaerobic digestion of acid cheese whey and dairy manure in a two-stage reactor. Bioresource Technol 58:61-72.

Kacprzak A., Krzystek L., Ledakowicz, S. 2010. Co-digestion of agricultural and industrial wastes. Chem Pap 64(2):127-31.

Krzystek L., Ledakowicz S., Kahle H.J., Kaczorek K. 2001. Degradation of household biowaste in reactors. J Biotechnol 92:103-12.

Lo K.V., Liao P.H. 1986. Digestion of cheese whey with anaerobic rotating biological contact reactor. Biomass 10:243-52.
Mace S., Bolzonella D., Cecchi F., Mata-Alvarez J. 2003. Comparison of the biodegradability of the grey fraction of municipal solid waste of Barcelona in mesophilic and thermophilic conditions. Water Sci Technol 48(4):21-28.

Mata-Alvarez J. (Ed.). 2003. Biomethanization of the Organic Fraction of Municipal Solid Wastes. IWA Publishing, London, UK.

Navickas K., Zuperka V., Janusauskas R. 2003. Energy input for cultivation and preparation of biomass for biogas production / LZUI instituto ir LZU universiteto mokslo darbai / LZUU 35(4):109-16.

Pavan P., Battistoni P., Mata-Alvarez J., Cecchi F. 2000. Performance of thermophilic semi-dry anaerobic digestion process changing the feed biodegradability. Water Sci Technol 41(3):75-82.

Rao M.S., Singh S.P. 2004. Bio energy conversion studies of organic fraction of MSW: kinetic studies and gas yield-organic loading relationships for process optimization. Bioresource Technol 95:173185.

Saint-Joly C., Desbois S., Lotti J.P. 2000. Determinant impact of waste collection and composition on anaerobic digestion performance: industrial results. Water Sci Technol 41(3):291-7.

Stretton-Maycock D., Merrington G. 2009. The use and application to land of MBT compost-like output - review of current European practice in relation to environmental protection. Science Report SC030144/SR3. Environment Agency, Bristol, UK.

Tchobanoglous G., Hilary T., Vigil S.A. 1997. Integrated solids waste management: engineering principles \& management issues. Mc Graw-Hill Inc.

Themelis N.J., Verma S. 2004. Anaerobic Digestion of Organic Waste in MSW. Waste Management World 20-24.

Ward A.J., Hobbs P.J., Holliman P.J., Jones D.L. 2008. Optimisation of the anaerobic digestion of agricultural resources (review article). Bioresource Technol 99(17):7928-40.

Yan J.Q., Lo K.V., Liao P.H. 1989. Anaerobic digestion of cheese whey using up-flow anaerobic sludge blanket reactor. Biol Waste 27:289305 . 